\title{
Microbial communities from the sea ice and adjacent water column at the time of ice melting in the northwestern part of the Weddell Sea
}

\author{
SYLVIE MATHOT, SYLVIE BECQUEVORT and CHRISTIANE LANCELOT
}

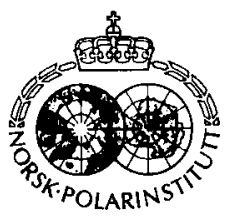

\begin{abstract}
Mathot, S., Becquevort. S. \& Lancelot. C. 1991: Microbial communities from the sea ice and adjacent water column at the time of ice melting in the northwestern part of the Weddell Sea. Pp. 267-275 in Sakshaug, E., Hopkins, C. C. E. \& Øritsland, N. A. (eds.): Proceedings of the Pro Mare Symposium on Polar Marine Ecology, Trondheim, 12-16 May 1990. Polar Research 10(1).

Microbial composition - including microalgae, bacteria and protozoans - and potential metabolic activity of its autotrophic compartment were measured in December 1988 in several micro-environments that characterise the North-West Sector of the marginal area of the Weddell Sea; infiltration and band assemblages of ice floes and adjacent waters were investigated. At the time of ice melting, a shift from a diatom dominated population (ice) to a flagellate dominated population (water column) was observed. Nevertheless, this shift was not due to an "inability" of the ice-diatoms to grow in the water colum. Macrograzing and/or sedimentation are suggested as possible causes of the disappearance of diatoms during ice melting. The remaining small autotrophic forms relcased by the ice would constitute a significant seeding stock for the growth of ice-edge blooms.
\end{abstract}

Sylvie Mathot, Sylvie Becquevort and Christiane Lancelot, Groupe de Microbiologie des Milieux Aquatiques, University of Brussels, CP 221, Campus de la Plaine, B.1050 Brussels, Belgium.

\section{Introduction}

The annual sea ice of the Southern Ocean provides suitable microhabitats for microalgae (Whitaker 1977; Ackley et al. 1979; Palmisano \& Sullivan 1983; Horner 1985; Garrison et al. 1986; Garrison \& Buck 1989b), heterotrophic flagellates and other protozoans (Garrison \& Buck 1989a; 1989b; Buck et al. 1990; Garrison \& Gowing 1992), as well as bacteria (Sullivan 1985; Kottmeier \& Sullivan 1987; Kottmeier et al. 1987). Indeed the sea ice offers a set of physicochemical conditions for microorganisms living in close association with it, either attached to ice crystals or suspended in the interstitial water between ice crystals (Horner 1985).

When released from the ice upon melting, the fate of ice-associated algae may be variable: part of the algae settles down (Schnack et al. 1985; von Bodungen et al. 1986), part is grazed by pelagic herbivores such as krill (Marschall 1988) or copepods (Fransz 1988), and part survives in the water column (Garrison \& Buck 1985). The latter part should constitute an inoculum for iceedge blooms that grow in the shallow, stable water column induced by the melting of pack ice (Garrison et al. 1986, 1987; Fryxell \& Kendrick
1988; Smith \& Nelson 1985, 1986; Sullivan et al. 1988). Accordingly, many of the nano- and microheterotrophic species are common to both ice and water (Garrison \& Gowing 1992), and those which seem to grow in ice after their initial incorporation (Garrison \& Buck 1989b) may produce an inoculum in the water column at the time of ice melting (Garrison \& Gowing 1992).

This study presents data concerning the structure of microbial communities originating from sea ice biota at the time of ice melting during the period of retreat of the ice edge. We have compared microbial inhabitants (microalgae, bacteria and protozoans) of several ice environments and adjacent water columns in the Weddell Sector of the Antarctic Ocean.

The possible genesis of an ice edge bloom through the release of living cells seeded into the water column depends not only on the physical properties of the adjacent water column, but also on the ability of the released ice-algae to be metabolically active. Thus, the potential activity of the primary producers released by the melting process also has been tested in a simulated seeding experiment under controlled conditions in filtered seawater. 


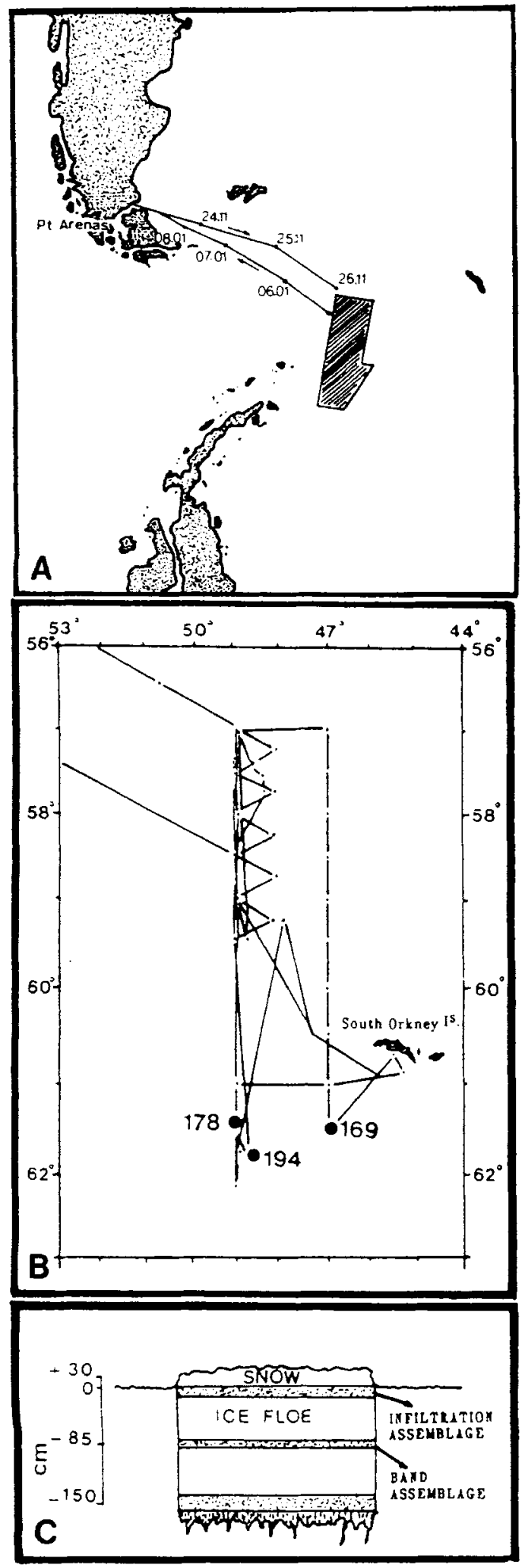

\section{Material and methods}

\section{Sampling}

Samples were collected during the European expedition EPOS leg 2 on board R/V POLARSTERN from 22 November, 1988, to 9 January, 1989. Three sites were investigated in December 1988 in the marginal ice zone of the northwestern Weddell Sea in an area extending from $47^{\circ}$ to $49^{\circ} \mathrm{W}$, between $61^{\circ}$ and $62^{\circ} \mathrm{S}$ (Fig. 1A and B).

Referring to the terminology proposed by Horner et al. (1988), results presented here only concern the infiltration assemblage located at the snow-ice interface of floes (Stations 169 and 194), and the band assemblage which appeared as a brown coloured band in the middle $(60$ to $80 \mathrm{~cm}$ from the top of the ice floe) of cores taken at Station 178 (Fig. 1C). Bottom assemblages were inconspicuous in the study area. To reduce osmotic shock (Garrison \& Buck 1986), ice samples were melted in sterile, filtered seawater in the dark prior to fixative addition or experiment start. Ice assemblages were sampled randomly. For comparison between ice and water environments, samples of seawater were also collected directly under the ice floes.

\section{Microscopical analysis}

Qualitative and quantitative analysis of plankton was carried out using two different microscopical methods: 1) Microplankton samples (mainly diatoms, ciliates, dinoflagellates), preserved with modified Lugol's solution (Thomas pers. comm.), were analysed in settling chambers using the inverted microscope technique of Utermöhl (1958); 2) Nanoplankton (mainly autotrophic and heterotrophic flagellates) and bacterioplankton samples fixed respectively with glutardialdehyde ( $0.5 \%$ final conc.) and formalin ( $2 \%$ final conc.) were analysed by epifluorescence microscopy after 4'6 diamidino-2-phenylindole (DAPI) staining according to the procedure of Porter \& Feig (1980).

In both methods, cell volumes were calculated from measurements of the dimensions and shapes

Fig. 1. Sampling area and sites: A. Location of the sampling area in the Southern Ocean; B. Cruise track of Nov. 1988Jan. 1989 EPOS Leg 2 expedition in the Scotia/Weddell Sea area, showing the ice stations sampled; $C$. Schematic representation of the sea ice biota sampled, with a vertical scale (in $\mathrm{cm}$ ) of the thickness of ice floes. 
of cells. In the case of diatoms, cell volumes were converted to carbon biomass according to Edler's (1979) recommendations using a conversion fac-

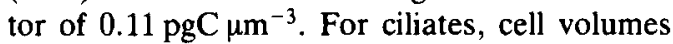
were converted to carbon values using the con-

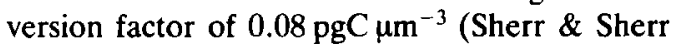

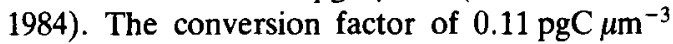
(Edler 1979) was used for autotrophic and heterotrophic flagellates. Concerning the bacteria, biovolumes were estimated on the enlargements of microphotographs. Conversion into carbon biomass was done using the biovolume dependent $\mathrm{C}$ /biovolume ratio proposed by Simon \& Azam (1989).

\section{Activity measurements}

The experimental determination of photosynthetic parameters involved short-term ${ }^{14} \mathrm{C}$ incubation (Steemann-Nielsen standard method) performed at different light intensities (P-I curves). Bottles (Cel-Cult) tissue culture flasks of 60,250 and $700 \mathrm{ml}$ were incubated in a water bath with running seawater at in situ temperature illuminated by artificial light. Maximum irradiance reached $135 \mu \mathrm{mol} \mathrm{m} \mathrm{m}^{-2} \mathrm{~s}^{-1}$, i.e. very close to the light saturation constant characteristic of antarctic phytoplankton. ${ }^{14} \mathrm{C}$ incubations were conducted at in situ temperature for different fractions of light intensity $(0,1,4,6,15,20,40$, $60,100 \%$ ). Incubation times of $4-6$ hours were chosen after a preliminary study of P-I curves for different incubation times. This choice minimises losses by respiration and increases accuracy. After incubation, samples were filtered on GF/F filters. Radioactivity was measured on the filter (photosynthetic carbon fixation) and in the dissolved organic matter (excretion). However, radioactivity of the latter was never significantly different from that of the background. Excretion was therefore assumed to represent a maximum of $5 \%$ of total photosynthesis. Photosynthetic parameters $K_{\max }, \alpha$, and $\beta$ were then statistically estimated by means of the Platt et al. equation (1980).

\section{Results}

\section{Primary producers and potential activities}

Figs. 2 and 3 show algal uptake of carbon as a function of irradiance for typical infiltration (Fig.
2A) and band (Fig. 3A) algal assemblages as well as their respective water column phytoplanktonic assemblages (Figs. 2B and 3B). Carbon uptake has been normalised to "active" carbon biomass calculated from cell counts and biovolume measurements. Thus, only carbon associated with vegetative, healthy autotrophic cells has been taken into account; this was a necessary correction since resting spores accounted for nearly half $(45 \%)$ of the total autotrophic carbon in the band assemblage. Photosynthetic characteristics of the populations as computed by statistical fitting of experimental data using the Platt et al. equation (1980) are presented in Table 1 . From examination of the P-I curves, it is obvious that, apart from the band assemblages (Fig. 3A), which revealed a low maximum specific rate of photosynthesis (see Table 1, mean $K_{m}=0.012 h^{-1}$ ), the infiltration assemblages exhibited similar values (Fig. 2A, Table 1, mean $\mathrm{K}_{\mathrm{m}}=0.049 \mathrm{~h}^{-1}$ ) to those
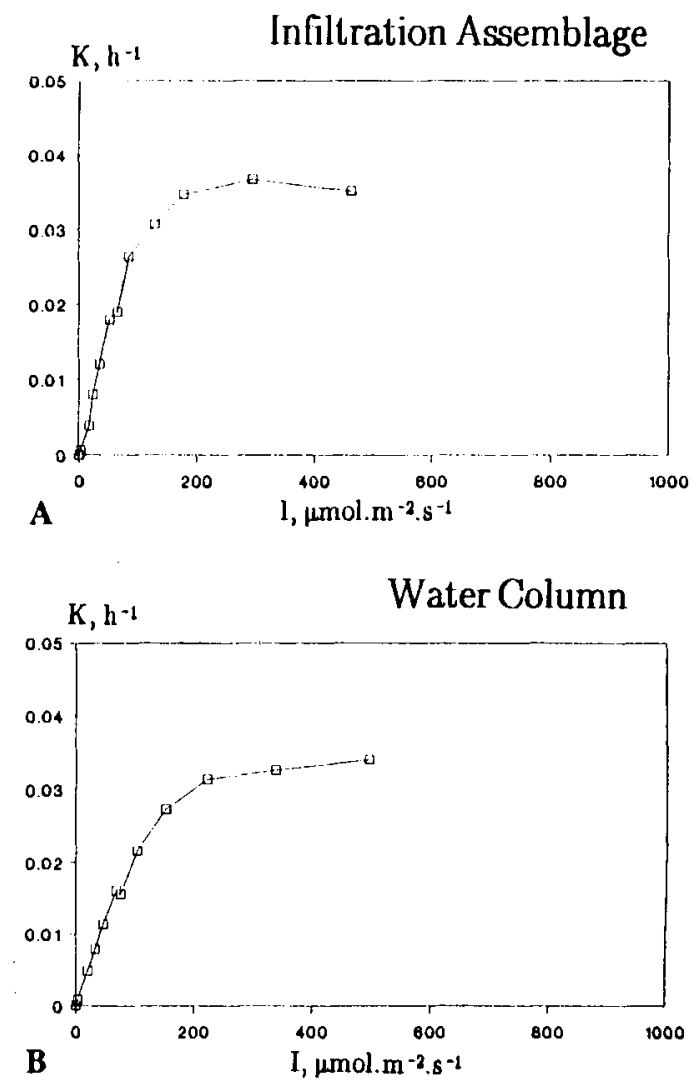

Fig. 2. Photosynthesis-irradiance relationship of natural populations sampled $(A)$ in the infiltration assemblage and $(B)$ in the adjacent water column. 

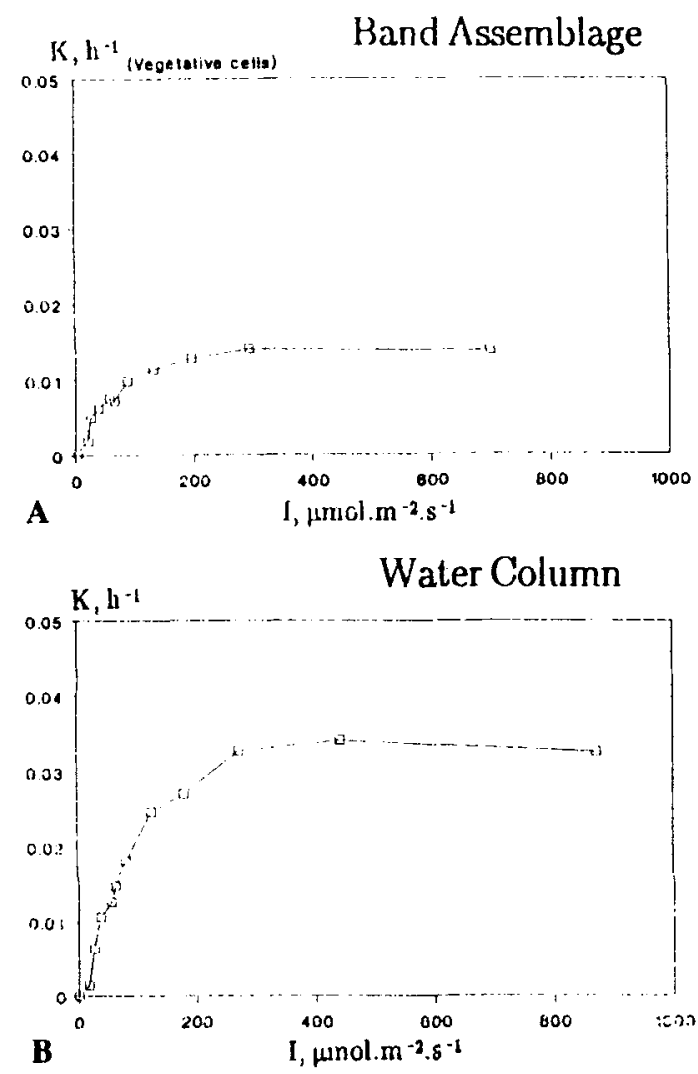

Fig. 3. Photosynthesis-irradiance relationship of natural popuJations sampled (A) in the band assemblage and (B) in the adjacent water column. For the band assemblage, only vegetative cells have been considered.

of the water column phytoplankton (Fig. 2B and $3 B$, Table 1 , mean $K_{m}=0.041 h^{-1}$ ). Photosynthetic efficiencies were in the same order of magnitude for infiltration and water column assemblages, ranging between $0.00066 \mathrm{~h}^{-1}$ $\left(\mu \mathrm{mol} \mathrm{m} \mathrm{m}^{-2} \mathrm{~s}^{-1}\right)^{-1}$ for the former and
$0.00047 \mathrm{~h}^{-1}\left(\mu \mathrm{mol} \mathrm{m} \mathrm{m}^{-2} \mathrm{~s}^{-1}\right)^{-1}$ for the latter. $I_{k}$ (index of photoadaptation) values were higher for infiltration and water column assemblages than for the band assemblages, being 75 and $92 \mu \mathrm{mol} \mathrm{m}^{-2} \mathrm{~s}^{-1}$ for the former, and much lower for the latter (Table 1). Thus photosynthesisirradiance relationships did not exhibit clear variations between infiltration assemblage and the surrounding water column, and both communities were similarly well adapted to prevailing physicochemical conditions.

\section{"Taxonomic" composition}

The dominant autotrophic taxons present in the different environments, i.e. ice assemblages and the adjacent water column, are summarised in Table 2A. Results are expressed as percentages of total autotrophic cell number. This table reveals a predominantly algal community with pennate diatoms always dominant in the ice assemblages (mean $=74 \%$ for infiltration assemblage $;$ mean $=$ $82 \%$ for band assemblage). The diatoms were mainly of the genus Nitzschia (up to $94 \%$ of autotroph cell number, e.g. $N$. closterium, $N$. cylindrus, $N$. curta, $N$. kerguelensis), but also genera such as Tropidoneis and Amphiprora, which presented a certain variability within each type of ice assemblage as well as in between the two types studied, were present (Table 2A).

Centric diatoms were scarce - if at all present in the infiltration assemblages, whereas they accounted for 1.4 and $32 \%$ of autotroph cell numbers in the band assemblages, both as vegetative cells and resting spores.

Autotrophic flagellates were not abundant in the ice assemblages, and even if they did reach $51 \%$ of the autotrophic cell number (Table $2 \mathrm{~A}$ ) in a particular infiltration sample, their con-

Table 1. Photosynthetic characteristics of the infiltration assemblage and the band assemblage (= vegetative cells only, with exclusion of the resting spores) from ice communities and of phyroplankton from the water column.

\begin{tabular}{|c|c|c|c|c|}
\hline & $n$ & $\alpha$ & $\mathrm{K}_{\mathrm{m}}$ & $I_{k}$ \\
\hline Infiltr. Ass. & 2 & $0.00066 \pm 0.00007$ & $0.049 \pm 0.003$ & $75 \pm 12.8$ \\
\hline Band Ass. & 2 & $0.00018 \pm 0.00007$ & $0.012 \pm 0.007$ & $62 \pm 15.7$ \\
\hline Phytoplankton & 6 & $0.00042 \pm 0.00016$ & $0.041 \pm 0.014$ & $92 \pm 19$ \\
\hline \multicolumn{5}{|c|}{$n:$ number of samples. } \\
\hline \multicolumn{5}{|c|}{$\alpha$ : photosynthetic cfficiency $\left[\mathrm{h}^{-1}\left(\mu \mathrm{mol} \mathrm{m} \mathrm{m}^{-2} \mathrm{~s}^{-1}\right)^{-1}\right]$. } \\
\hline \multicolumn{5}{|c|}{$\mathrm{K}_{\mathrm{m}}$ : maximal specific rate of photosynthesis $\left(\mathrm{h}^{-1}\right)$. } \\
\hline \multicolumn{5}{|c|}{$I_{k}$ : light adaptation parameter $\left(\mathrm{K}_{\mathrm{m}} / \alpha ; \mu \mathrm{mol} \mathrm{m}^{-2} \mathrm{~s}^{-1}\right)$. } \\
\hline
\end{tabular}


Table 2. A. Composition of the autotrophic community encountered in the different environments sampled. Results expressed as percentage of total autotrophic cell number. $(-)=$ negligible.

\begin{tabular}{|c|c|c|c|c|c|c|}
\hline \multirow[b]{2}{*}{ Taxon } & \multicolumn{2}{|c|}{$\begin{array}{l}\text { Infilt. Assemblage } \\
\mathrm{n}=4\end{array}$} & \multicolumn{2}{|c|}{$\begin{array}{l}\text { Band Assemblage } \\
\mathrm{n}=2\end{array}$} & \multicolumn{2}{|c|}{$\begin{array}{l}\text { Water Column } \\
\mathrm{n}=3\end{array}$} \\
\hline & Range, & $\overline{\mathbf{x}}$ & Range, & $\overline{\mathbf{x}}$ & Range, & $\overline{\mathrm{x}}$ \\
\hline \multicolumn{7}{|l|}{$\begin{array}{l}\text { Pennate } \\
\text { diatoms }\end{array}$} \\
\hline Nitzschia sp. & $41-94$ & $70.7 \pm 15$ & $57-82$ & $70 \pm 12.5$ & $9-13$ & $10.3 \pm 1.8$ \\
\hline Tropidoneis sp. & $0-7$ & $2.5 \pm 2.5$ & $1.6-2$ & $1.8 \pm 0.2$ & $(-)$ & \\
\hline Amphiprora sp. & $0-1$ & $0.3 \pm 0.4$ & $6.5-15$ & $10.8 \pm 4.3$ & $(-)$ & \\
\hline $\begin{array}{l}\text { Centric } \\
\text { diatoms }\end{array}$ & $(-)$ & & $1.4-32$ & $16.7 \pm 15.3$ & $(-)$ & \\
\hline \multicolumn{7}{|l|}{ Flagellates } \\
\hline Dinoflagellates & $0-2$ & $1.0 \pm 1.0$ & $0-2.5$ & $1.3 \pm 1.3$ & $2-3$ & $2.7 \pm 0.4$ \\
\hline Nanoflagellates & $0-51$ & $25 \pm 13$ & $(-)$ & & $85-89$ & $87.3 \pm 1.6$ \\
\hline
\end{tabular}

tribution to the autotrophic total biomass (Table $3 \mathrm{~A})$ remained negligible compared to that of diatoms. Thus, the autotrophic composition of the ice assemblages was highly variable and showed a patchy distribution of microalgae, reflecting the heterogeneity of the ice environment.

In contrast, the composition of autotrophic communities of the adjacent water column was constant and homogeneous, without any conspicuous differences between the different localities. Indeed, Nitzschia sp. was the only diatom present, accounting for only 9 to $13 \%$ (mean = $10 \%$ ) of the autotroph cell numbers (Table 2A), whereas the bulk of the autotrophic population consisted of flagellated cells (85-89\% autotrophic nanoflagellates including Cryptomonas spp., Pyramimonas spp., Phaeocystis pouchetii; 1-3\% autotrophic dinoflagellates). In terms of biomass (Table 3A), diatoms represented about one-fifth of the total autotrophic biomass (range $=19$ $25 \%$, mean $=21 \%$ ), and autotrophic flagellates occupied the remaining four-fifths, with a net dominance of nanoflagellates (range $=64-72 \%$, mean $=69 \%$ ) other than dinoflagellates (range $=$ $3-18 \%$, mean $=10 \%$ ).

Concerning the protozooplankton abundance in the three environments considered (Table 2B), there were no differences between infiltration assemblages and water column assemblages in the composition of the groups, with net dominance of heterotrophic nanoflagellates $(95-99 \%$ of heterotrophic cell number) over heterotrophic dinoflagellates $(1-5 \%)$. The biomass of heterotrophic dinoflagellates (Table $3 \mathrm{~B}$ ) was higher (mean $=31 \%$ of total heterotrophic carbon) than that of the heterotrophic nanoflagellates (mean $=$ $20 \%$ of total heterotrophic carbon) in the infiltration assemblages, whereas in the water column, the non-dinoflagellate heterotrophic nanoflagellates dominated the flagellated fraction (see Table 3B). Ciliates were not significant although this group did contribute to some extent

Table 2. B. Composition of the protozoan community encountered in the different environments sampled. Results expressed as percentage of total protozoan cell number.

\begin{tabular}{|c|c|c|c|c|c|c|}
\hline \multirow[b]{2}{*}{ Taxon } & \multicolumn{2}{|c|}{$\begin{array}{l}\text { Infilt.Assemblage } \\
n=4\end{array}$} & \multicolumn{2}{|c|}{$\begin{array}{l}\text { Band Assemblage } \\
\mathrm{n}=2\end{array}$} & \multicolumn{2}{|c|}{$\begin{array}{l}\text { Water Column } \\
n=3\end{array}$} \\
\hline & Range, & $\overline{\mathbf{x}}$ & Range, & $\overline{\mathrm{x}}$ & Range, & $\overrightarrow{\mathrm{x}}$ \\
\hline Ciliates & $(-)$ & & $30-80$ & $55 \pm 25$ & $(-)$ & \\
\hline \multicolumn{7}{|l|}{ Flagellates } \\
\hline Dinoflagellates & $1-5$ & $3.5 \pm 1.3$ & $20-70$ & $45 \pm 25$ & $1-4$ & $3 \pm 1.3$ \\
\hline Nanoflagellates & $95-99$ & $96.5 \pm 1.3$ & $(-)$ & & $96-99$ & $97 \pm 1.3$ \\
\hline
\end{tabular}




\section{S. Mathot, S. Becquevort \& C. Lancelot}

Table 3. A. Composition of the autotrophic biomass encountered in the various environments sampled. Results expressed as percentage of total autotrophic carbon biomass. $(-)=$ negligible.

\begin{tabular}{|c|c|c|c|c|c|c|}
\hline \multirow[b]{2}{*}{ Taxon } & \multicolumn{2}{|c|}{$\begin{array}{l}\text { Infilt. Assemblage } \\
n=4\end{array}$} & \multicolumn{2}{|c|}{$\begin{array}{l}\text { Band Assemblage } \\
n=2\end{array}$} & \multicolumn{2}{|c|}{$\begin{array}{l}\text { Water Column } \\
n=3\end{array}$} \\
\hline & Range. & $\tilde{\mathrm{x}}$ & Range. & $\bar{x}$ & Range. & $\overline{\mathbf{x}}$ \\
\hline Diatoms & $78-95$ & $84 \pm 5.6$ & $98-99$ & $98.5 \pm 0.5$ & $19-25$ & $21.3 \pm 2.4$ \\
\hline \multicolumn{7}{|l|}{ Flagellates } \\
\hline Phaeocystic col & $0-4$ & $1.5 \pm 1.5$ & $(-)$ & & $(-)$ & \\
\hline Dinoflagellates & $1-14$ & $6.5 \pm 4$ & $0-0.5$ & $0.3 \pm 0.5$ & $3-18$ & $10.7 \pm 5.1$ \\
\hline Nanoflagellates & $3-14$ & $7.5 \pm 4.5$ & $0.5-1$ & $0.8 \pm 0.3$ & $64-72$ & $68.7 \pm 3.1$ \\
\hline Cyanobacteria & $0.3-2.2$ & $1 \pm 0.6$ & $(-)$ & & $(-)$ & \\
\hline
\end{tabular}

Table 3. B. Composition of the heterotrophic biomass encountered in the various environments sampled. Results expresscd as percentage of total heterotrophic biomass.

\begin{tabular}{|c|c|c|c|c|c|c|}
\hline \multirow[b]{2}{*}{ Taxon } & \multicolumn{2}{|c|}{$\begin{array}{l}\text { Infilt. Assemblage } \\
\mathbf{n}=4\end{array}$} & \multicolumn{2}{|c|}{$\begin{array}{l}\text { Band Assemblage } \\
n=2\end{array}$} & \multicolumn{2}{|c|}{$\begin{array}{l}\text { Water Column } \\
n=3\end{array}$} \\
\hline & Range. & $\overline{\mathbf{x}}$ & Range, & $\overline{\mathbf{x}}$ & Range, & $\overline{\mathrm{x}}$ \\
\hline \multicolumn{7}{|l|}{ Protozoa } \\
\hline Ciliates & $4-13$ & $8 \pm 3.6$ & $6.2-69.3$ & $38 \pm 31.6$ & $5-10$ & $7.2 \pm 2.1$ \\
\hline Dinoflagellates & $10-55$ & $31 \pm 19.7$ & $0-1.3$ & $0.1 \pm 0.07$ & $9-32$ & $19.3 \pm 8.3$ \\
\hline Nanofiagellates & $5-41$ & $20 \pm 10.6$ & $(-)$ & & $19-31$ & $25 \pm 4$ \\
\hline Bacteria & $16-59$ & $41 \pm 12.6$ & $29-94$ & $62 \pm 32.2$ & $33-67$ & $48.5 \pm 12.2$ \\
\hline
\end{tabular}

Table 4. Composition of microorganisms in the sea ice and adjacent water column samples. Results expressed in percentage of total carbon biomass (autotrophs + heterotrophs). Diatoms R.S. $=$ Resting Spores; Diatoms V.C. $=$ Vegetative Cells. $(-)=$ negligible.

\begin{tabular}{|c|c|c|c|c|c|c|}
\hline Taxon & \multicolumn{2}{|c|}{$\begin{array}{l}\text { Infilt. Assemblage } \\
n=4\end{array}$} & \multicolumn{2}{|c|}{$\begin{array}{l}\text { Band Assemblage } \\
\mathrm{n}=2\end{array}$} & \multicolumn{2}{|c|}{$\begin{array}{l}\text { Water Column } \\
n=3\end{array}$} \\
\hline \multicolumn{7}{|l|}{ Autotrophs } \\
\hline Diatoms R.S. & $(-)$ & & $12-45$ & $29 \pm 16.2$ & $(-)$ & \\
\hline Diatoms V.C. & $65-93$ & $77 \pm 8.7$ & $50-63$ & $56.5 \pm 6$ & $11-15$ & $13.4 \pm 1.6$ \\
\hline Phaeocystis col & $0-3.3$ & $1.2 \pm 1.2$ & $(-)$ & & $(-)$ & \\
\hline Dinoflagellates & $1-11$ & $5.6 \pm 3.2$ & $0-0.3$ & $0.2 \pm 0.2$ & $2-10$ & $6.7 \pm 3.2$ \\
\hline Nanoflagellates & $3-13$ & $6.9 \pm 4.3$ & $0.2-1$ & $0.6 \pm 0.4$ & $38-50$ & $43.6 \pm 4$ \\
\hline Cyanobacteria & $0.1-1.8$ & $0.9 \pm 0.6$ & $(-)$ & & $(-)$ & \\
\hline Total & $82-97$ & $92 \pm 4.8$ & $76-96$ & $86 \pm 10$ & $60-71$ & $64 \pm 14.7$ \\
\hline \multicolumn{7}{|l|}{ Heterotrophs } \\
\hline Ciliates & $0.1-2.4$ & $0.9 \pm 0.7$ & $1.4-2.9$ & $2.2 \pm 0.8$ & $1.9-3$ & $2.5 \pm 0.4$ \\
\hline Dinoflagellates & $0.4-4.5$ & $2.1=1.2$ & $0-0.1$ & $0.05 \pm 0.05$ & $3.8-9$ & $6.5 \pm 1.8$ \\
\hline Nanoflagellates & $0.2-3$ & $1.6 \pm 0.7$ & $0-0.6$ & $0.3 \pm 0.3$ & $7-12$ & $9 \pm 2.1$ \\
\hline Bacteria & $1.3-11$ & $3.8 \pm 3.5$ & $1.3-22$ & $12 \pm 10.4$ & $9-27$ & $18.2 \pm 5.9$ \\
\hline Total & $3-18$ & $8.3 \pm 4.9$ & $4-24$ & $14 \pm 10$ & $29-40$ & $36.3 \pm 4.9$ \\
\hline
\end{tabular}




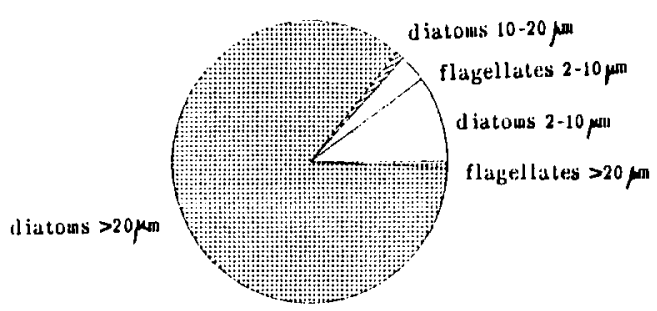

$\mathbf{A}$ Infiltration Assemblage

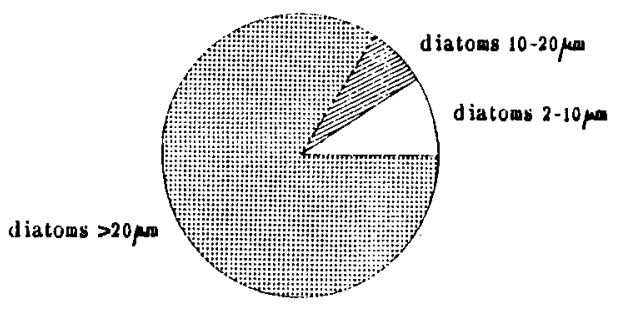

B
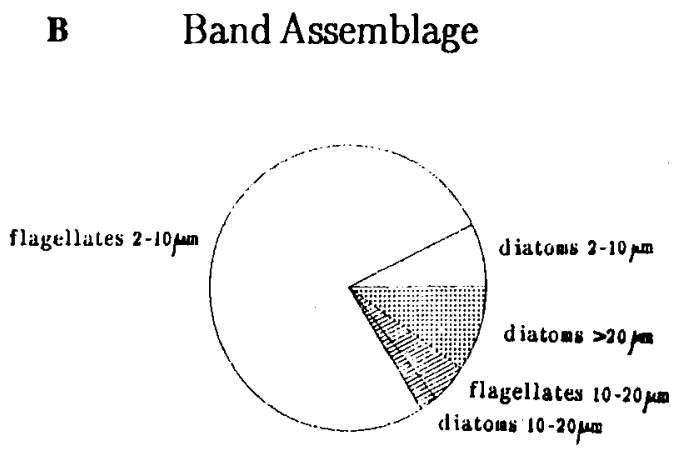

C
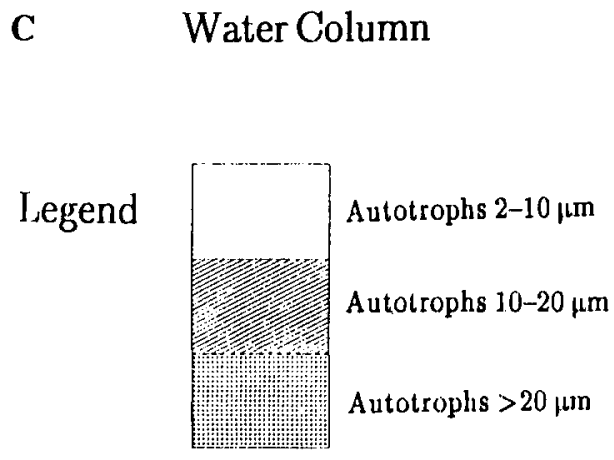

Fig. 4. Composition of the total autotrophic biomass in three size classes of distribution, with distinction between diatoms and flagellates in each size range: $A$. Infiltration assemblage $169 / 1$; B. band assemblage $178 / 1$; C. water column assemblage 194. to the total heterotrophic biomass (Table 3B), with mean values of $8 \%$ for the infiltration assemblages, and $7 \%$ for the water column.

In the band assemblages, heterotrophic nanoflagellates were present in negligible numbers compared to heterotrophic dinoflagellates and ciliates, which showed a great heterogeneity in their respective distributions (Table $2 \mathrm{~B}$ ).

\section{Discussion}

Relative proportions - in terms of biomass - of autotrophs (diatoms, dinoflagellates, nanoflagellates and cyanobacteria) as well as heterotrophs (ciliates, dinoflagellates, nanoflagellates, and bacteria) are shown in Table 4 for both ice and water column communities.

Floristic analysis of the ice assemblages showed a clear dominance of diatoms over other autotrophs (65-95\% of total biomass). Moreover, comparison of ice assemblages indicated the presence of resting spores in the band assemblages, suggesting that these might be remnants from a sub-ice algal bloom from the previous year, which were "trapped" in two-year-old ice according to Ackley et al. (1979) and McConville \& Wetherbee (1983).

In contrast, diatoms in the water column constituted a minor fraction never exceeding $15 \%$ (Table 4); the bulk of the biomass was contributed by the autotrophic flagellates ( 45 to $57 \%$ ) with a net dominance of the nanoflagellated fraction (78-96\%). These results seem to contradict observatons made by Garrison \& Buck (1985), Garrison et al. (1986) and Smith \& Nelson (1986), all of whom found great similarity among assemblages from ice floes and from planktonic populations, supporting the seeding hypothesis from the ice to the water column. Our results, however, do not exclude the potential role of seeding, but do indicate that other factors (such as early grazing by macrozooplankton) can prevent seeding of the water column assemblages.

Note that unlike Fryxell \& Kendrick (1988) who suggested that Phaeocystis colonies found in the water column in the same area could have been seeded from the melting ice, Phaeocystis colonies were present in two of our infiltration samples where they accounted for 1 and $3 \%$ of the total biomass, but no colonies were observed in the surrounding waters.

In the ice assemblages, the autotroph/ 
heterotroph biomass ratio was quite different from one sample to another, ranging between 3 and 33. In contrast, water samples presented a lower and remarkably constant ratio (1.5-2.5). The relative proportions of heterotrophs were always more important in the water column than in the ice environment, although protozoans (including flagellates and ciliates) and bacteria are regular and abundant components of the ice biota (Garrison et al. 1986). The abundance of heterotrophs in the ice environment indicates an active food web within the ice community (Garrison \& Buck 1989b). In fact, the relative proportions of heterotrophs were greater in the water column since only a part of total autotrophic biomass remained in the water column at the time of ice melting.

This accounts for the shift observed from a diatom dominated population (ice) to a flagellate dominated population (water column) at the time of ice melting. However, as has been shown previously (Table 1, Fig. 2), this shift cannot be explained by an "inability" of the ice communities - at least for their autotrophic constituents - to grow in the water column, but rather by an effective disapppearance from the water column, either by grazing pressure (macrozooplankton) or sedimentation processes.

Indeed, euphausiids have been shown to follow the retreating ice edge, taking advantage of the elevated food supply when the ice is melting (see Sakshaug \& Skjoldal 1989). During the EPOS Leg 2 expedition, Cuzin-Roudy \& Schalk (1989) reported an abundance of krill under ice floes, indicating that sea ice can provide a nursery ground for larval krill (Marshall 1988) which feed on particles released by the melting infiltration and band assemblages. Smetacek et al. (1990) even presents a hypothetical annual cycle where krill switch from scraping ice algae to filtering phytoplankton. The disappearance of diatoms but not of flagellates does not seem to reflect selection of "species" but rather of particle size. As seen in Fig. 4, the distribution of autotrophs in the various size ranges is inverted when going from the ice environment to the water column. This figure shows an example of autotrophic biomass distribution in three size ranges $(2-10 \mu \mathrm{m}, 10$ $20 \mu \mathrm{m},>20 \mu \mathrm{m})$ for an infiltration assemblage (Fig. 4A), a band assemblage (Fig. 4B) and a water column phytoplanktonic community (Fig. $4 C$ ), with separation between diatom and flagellate biomass contribution within each size range. Although krill is capable of feeding on very small particles, large cells are taken more efficiently (Segawa et al. 1983; Boyd et al., 1984). Meyer \& El-Sayed (1983) also showed the preferential feeding on micro-sized $(20-200 \mu \mathrm{m})$ particles by krill.

On the other hand, because of the spatial constraint of living in the ice environment, the growth of ice algae can occur in aggregated entities in between ice crystals (Tropidoneis vanheurckii often aggregated in our samples). These observations are in accordance with experimental results obtained by Riebesell et al. (1991) collected during the same EPOS expedition. Being heavier, these aggregates could, together with larger cells, sink out of the surface mixed layer leaving small cells and flagellates in the adjacent water column. In fact, high sedimentation following spring blooms has been reported as being one of the fates (Schnack et al. 1985) if not the dominant one (von Bodungen et al. 1986) of iceedge blooms.

In summary, by comparing the floristic composition of the ice environment with that of the water column following ice melting, an obvious shift from a diatom dominated population in the ice environment to a flagellated one in the water column was observed, with an apparently negligible seeding effect of ice algae into the water column. When analysing the photosynthetic capabilities of these ice algal communities (infiltration assemblages being largely dominant over band assemblages in the area of the Weddell Sea we visited), there is clear evidence that they could grow at the same rate as the water column assemblages. Thus, other factors such as grazing by pelagic herbivores or sedimentation at very early stages during and after melting of the ice might significantly modify the structure of ice-associated microbial communities entering the water column.

Acknowledgements. - We thank R. Sharek and E-M. Nöthig for helping in the initial identification of ice algae. V. Smetacek. E. Sakshaug and two anonymous reviewers provided valuable comments to the manuscript. This work is part of the Belgian Scientific Research Programme on Antartica, funded by the Science Policy Office (Brussels, Belgium), under contract $\mathrm{Nr}$ ANTAR/05. Data presented here were collected during the European Polarstern Study (EPOS) sponsored by the European Science Foundation and the Alfred Wegener Institute for Polar and Marine Research, Bremerhaven.

\section{References}

Ackley. S. F., Buck. K. R. \& Taguchi, S. 1979: Standing crop 
of algae in the sea ice of the Weddell Sea region. Deep-Sea Res. 26A, 269-282.

Boyd, C. M., Heyraud, M. \& Boyd, C. N. 1984: Feeding of the Antarctic krill Euphausia superba. J. Crustacean Biol. 4, 123-141.

Buck, K. R., Bolt, P. A. \& Garrison, D. L. 1990: Phagotrophy and fecal pellet production by an athecate dinofiagellate in Antarctic sea ice. Mar. Ecol. Prog. Ser. 60, 75-84.

Cuzin-Roudy, J. \& Schalk, P. H. 1989: Macrozooplankton Biomass, development and activity. Pp. 146-159 in Hempel, I. Schalk, P. H. \& Smetacek, V. (eds.): The Expedition Antarktis VII/3 (EPOS LEG 2) of R/V "Polarstern" in 1988/ 89. Reports on Polar Research.

Edler, L. 1979: Recommendations for marine biological studies in the Baltic Sea - Phytoplankton and Chlorophyll. Baltic Marine Biologists 5, 1-38.

Fransz, H. G. 1988: Vernal abundance, structure and development of epipelagic copepod populations of the Eastern Weddell Sea (Antarctica). Polar Biol. 9, 107-114.

Fryxell, G. A. \& Kendrick, G. A. 1988: Austral spring microalgae across the Weddell Sea ice edge: spatial relationships found along a northward transect during AMERIEZ 83. Deep-Sea Res. 35, 1-20.

Garrison, D. L. \& Buck, K. R. 1985: Sea-ice algal communities in the Weddell Sea: species composition in ice and plankton assemblages. Pp. 103-122 in Gray, J. S. \& Christiansen, M. E. (eds.): Marine Biology of Polar Regions and Effects of Stress on Marine Organisms. John Wiley and Sons.

Garrison, D. L. \& Buck, K. R. 1986: Organism losses during ice melting: a serious bias in sea ice community studies. Polar Biol. 6, 237-239.

Garrison, D. L. \& Buck, K. R. 1989(a): Protozooplankton in the Weddell sea, Antartica: Abundance and distribution in the ice-edge zone. Polar Biol. 9, 341-351.

Garrison, D. L. \& Buck, K. R. 1989(b): The biota of antarctic pack ice in the Weddell Sea and Antarctic Peninsula regions. Polar Biol. 10, 211-219.

Garrison, D. L. \& Gowing, M. M. 1992: Protozooplankton. In Friedmann, E. I. (ed.): Antarctic Microbiology. In press.

Garrison, D. L., Buck, K. R. \& Fryxell, G. A. 1987; Algal assemblages in Antarctic pack ice and in ice-edge plankton. J. Phycol. 23, 564-572.

Garrison, D. L., Sullivan, C. W. \& Ackley, S. F. 1986: Sea ice communities in Antarctica. BioScience 36, 243-249.

Horner, R. A. 1985: Ecology of sea ice microalgae. pp. 83-103 in Horner, R. A. (ed.): Sea lce Biota. CRC Press, Boca Raton.

Horner, R. A.. Syvertsen, E. E., Thomas, D. P. \& Lange, C. 1988: Proposed terminology and reporting units for Sea ice Algal Assemblages. Polar Biol. 8, 249-253.

Kottmeier, S. T., McGrath Grossi, S. \& Sullivan, C. W. 1987: Sea ice microbial communities: 8 . Bacterial production in annual sea ice of McMurdo Sound, Antarctica. Mar. Ecol. Prog. Ser. 35, 175-186.

Kottmeier, S. T. \& Sullivan, C. W. 1987: Late winter primary production and bacterial production in sea ice and seawater west of the Antarctica Peninsula. Mar. Ecol. Prog. Ser. 36, 287-298.

Marschall, H. P. 1988: The overwintering strategy of Antarctic krill under the pack-ice of the Weddell Sea. Polar Biol. 9, 129-135.

Meyer, M. A. \& El-Sayed, S. Z. 1983: Grazing of Euphausia superba Dana on natural phytoplankton populations. Polar Biol. 1, 193-203.
McConville, M. J. \& Wetherbee, R. 1983: The bottom-ice microalgal community from annual ice in the inshore waters of east Antarctica. J. Phycol. 19, 431.

Palmisano, A. C. \& Sullivan C. W. 1983: Sea Ice Microbial Communities (SIMCO) 1. Distribution, Abundance, and Primary Production of Ice Microalgae in McMurdo Sound, Antarctica in 1980. Polar Biol. 2, 171-177.

Platt, T., Gallegos, L. L. \& Harrison, W. G. 1980: Photoinhibition of photosynthesis in natural assemblages or marine phytoplankton. J. Mar. Res. 38, 687-701.

Porter, K. G. \& Feig, Y. S. 1980: the use of DAPI for identifying and counting aquatic microflora. Limnol. Oceanogr. 25(5), 943-948.

Riebesell, U., Schloss, I., \& Smetacek, V. 1991: Aggregation of algae released from melting sea ice: Implications for seeding and sedimentation. Polar Biol. 11, 239-248.

Sakshaug, E. \& Skjoldal, H. R. 1989: Life at the ice edge. Ambio 18(1), 60-67.

Schnack, S. B., Smetacek, V. S., von Bodungen. B. \& Stegmann, P. 1985: Utilization of phytoplankton by copepods in Antarctic Waters during spring. Pp. 65-81 in Gray, J. S. \& Christiansen, M. E. (eds.): Marine Biology of Polar Regions and Effects of Stress on Marine Organisms. John Wiley and Sons.

Segawa, S., Kato, M. \& Murano, M. 1983: Growth, moult and filtering rate of krill in laboratory conditions. Mem. Nall. Inst. Polar Res., Special lssue 27, 93-103.

Sherr, B. F. \& Sherr, E. B. 1984: Röle of heterotrophic protozoa in carbon and energy flow in aquatic ecosystems. Pp. 412-423 in Klug, M. J. \& Reddy, C. A. (eds.): Current Perspectives in Microbial Ecology. American Society for Microbiology, Washington, D.C.

Simon, M. \& Azam, F. 1989: Protein content and protein synthesis rates of planktonic marine bacteria. Mar. Ecol. Prog. Ser. 51, 201-213.

Smetacek, V., Sharek, R., \& Nöthig E-M. 1990: Seasonal and regional variation in the pelagial and its relationship to the life history cycle of krill. Pp. 103-114 in Kerry, K. R. and Hempel, G. (eds.): Antarctic Ecosystems. Ecological Change and Conservation. Springer-Verlag. Berlin.

Smith, W. O., Jr. \& Nelson, D. M. 1985: Phytoplankton bloom produced by a receding ice edge in the Ross Sea: spatial coherence with the density field. Science $227,163-166$.

Smith, W. O., Jr. \& Nelson, D. M. 1986: Importance of ice edge phytoplankton production in the Southern Ocean. BioScience 36, 251-257.

Sullivan, C. W. 1985: Sea ice bacteria: reciprocal interactions of the organisms and their environment. Pp. 159-171 in Horner, R. A. (ed.): Sea lce Biota. . CRC Press, Boca Raton. Sullivan, C. W., McClain, C. R., Comiso, J. C. \& Smith, W. O., Jr. 1988: Phytoplankton standing crops within an Antarctic ice edge assessed by satellite remote sensing. $J$. Geophys. Res. 93(C10), 12487-12498.

Utermöhl, H. 1958: Zur Vervollkornmnung der quantitativen Phytoplankton - Methodik. Mitt. Int. Verein. Theor. Angew. Limnol. 9. 1-38.

von Bodungen, B., Smetacek, V. S., Tilzer, M. M. \& Zeitzschel, B. 1986: Primary production and sedimentation during spring in the Antarctic Peninsula region. Deep-Sea Res. 33, 177-194.

Whitaker, T. M. 1977: Sea ice habitats of Signy Island (South Orkneys) and their primarry productivity. Pp. $75-83$ in Llano. G. A. (ed.): Adaptations within Antarctic ecosystems. Gulf Publishing, Houston. 
